\author{
SILVIA LANDI ${ }^{\mathrm{a}}$ - GIADA D'ERRICO ${ }^{\mathrm{b}}$ - ROSSELLA PAPINI $^{\mathrm{c}}$ - ELISABETTA GARGANI ${ }^{\mathrm{a}}$ \\ STEFANIA SIMONCINI $^{\text {a }}$ - TIZIANA AMORIELLO ${ }^{d}-$ ROBERTO CICCORITTI $^{\mathrm{e}}-$ KATYA CARBONE $^{\mathrm{e}}$
}

\title{
COMMUNITIES OF PLANT PARASITIC AND FREE-LIVING NEMATODES IN ITALIAN HOP CROPS
}

\begin{abstract}
${ }^{a}$ CREA Research Centre for Plant Protection and Certification, Via di Lanciola 12/A, 50125 Cascine del Riccio, Firenze, Italy. ${ }^{\mathrm{b}}$ Department of Agricultural Sciences, University of Naples Federico II, via Università 100, 80055 Portici, Napoli, Italy. ${ }^{\mathrm{C}}$ CREA Research Centre for Agriculture and Environment, Via di Lanciola 12/A, 50125 Cascine del Riccio, Firenze, Italy. ${ }^{\mathrm{d}}$ CREA Research Centre for Food and Nutrition, Via Ardeatina 546, 00178 Roma, Italy.

${ }^{\mathrm{e}}$ CREA Research Centre for Olive, Citrus and Tree Fruit, Via di Fioranello 52, 00134 Roma, Italy. Corresponding Author: Silvia Landi; silvia.landi@crea.gov.it
\end{abstract}

Landi S., d'Errico G., Papini R., Gargani E., Simoncini S., Amoriello T., Ciccoritti R., Carbone K. - Communities of plant parasitic and free-living nematodes in Italian hop crops.

The cultivation of hop has had a notable expansion due to growing interest of craft beer in Italy in the past few years. Thus, surveys were conducted to evaluate nematodes associated with the Italian hop cultivations. The aims of this work were to determine the occurrence of plant parasite and virus-vector nematodes and to evaluate the ecosystem services associated with the control of plant parasitic nematodes. Six different sites located in North and Central Italy were monitored to assess the structure of nematode communities. Many plant parasitic nematodes widely distributed in Italy were found in association with hop plants such as Mesocriconema xenoplax and Heterodera spp. The Xiphinema genus was the most abundant and ubiquitous plant parasitic nematode. The most frequent species were $X$. pacthaicum followed by $X$. diversicaudatum, the Arabis mosaic virus (ArMV)-vector. Predators were not able to regulate the ecosystem pest control service. The agronomic strategies that adopted less intensive tillage practices, such as minimum tillage or cover grass, showed the best regulation.

KeY Words: ecology, free-living nematodes, hop crop, North and Central Italy, plant parasitic nematodes.

\section{INTRODUCTION}

Over the last few decades, Italy has been assisting to the rise and the establishment of a new type of business in the brewing industry: the craft beer industry, which gained great success and credibility, becoming one of the most significant phenomenon of the Italian agri-food sector. The direct, indirect and induced contribution of the craft brewing sector to the Italian economy is becoming considerable, with approximately 600 microbreweries operating in the country, for an average annual beer production of 445,000 hectoliters, accounting for about $3 \%$ of the total volume of beer produced. Besides, Italy imports almost all the brewing raw materials, especially hop cones, the inflorescences of the female plant of Humulus lupulus L., which play a pivotal role as flavouring/bittering and preservative agent (CARBONE et al., 2017). In order to address the growing internal demand, several farmers have begun cultivating hops in different Italian regions. Currently, the hop cultivating area in Italy amounts to approximately 56 hectares with an average surface of $6351 \mathrm{~m}^{2}$ (www.luppolo.crea.gov.it).

As with many crops the occurrence of infection by pathogens and the establishment of infestations by harmful organisms such as arthropods and nematodes represent a limiting factor for hop crop cultivations and cause quantitative and qualitative yield losses. This risk is seriously aggravated by the presence of several weeds that may serve as pest or pathogen sources of inoculum (D'ERRICO et al., 2014). Given the recent interest in hop crop in Italy, surveys have been conducted to evaluate the phytosanitary status of the Italian hop crops (GARGANI et al., 2017) and nematode populations associated with this agroecosystem. The first records on the occurrence of nematodes in hop fields mainly showed the presence of Heterodera humuli Filipjev in Germany (VOIGT, 1894) and in England (PERCIVAL, 1895). Then, this species has been reported from USA, Canada, South Africa, New Zealand and in many European countries (DANILOVA YU, 1996). H. humuli is the obligate parasite hop cyst and represents the most common nematode species associated with hop. At present, this species has not been found in Italy (GARGANI et al., 2017). In general, plant parasitic nematodes associated with hop production are considered of minor importance (HAY, 2010), except for virus-vector species of the genus Xiphinema (VALDEZ et al., 1974). By contrast, few studies have been carried out to investigate the whole nematode community and its multiple roles within the soil food web (LIŠKOVÁ and RENČO, 2007). Several management factors still need to be addressed, such as the use of different agronomic practices, aimed to preserve biodiversity and ecosystem services with particular regard to regulative services for pest control (LANDI et al., 2018a). In fact, ecosystems are strongly affected by crop management strategies, soil chemical properties and soil microbial, nematode, microarthropod and plant communities (MocALI et al., 2015a; 2015b; LAZZARO et al., 2018).

The objectives of the present work were to i) determine the structure of nematode communities in Central and North Italy, the main Italian production areas, focusing on the occurrence of plant parasitic and virus-vector nematodes; ii) evaluate main ecosystem services associated with nematodes such as the control of plant parasitic nematodes. 


\section{MATERIALS AND METHODS}

FIELD SITES AND SOIL SAMPLING DESIGN

Six fields of approximately half hectare each, distributed in North and Central Italy, were surveyed (Fig. I). The characteristics of sites are reported in Table 1. Soil samples were collected from three different points of each field during summers 2017 and 2018. To determine soil texture, soil pH and Total Organic Carbon (TOC), samples were taken at 0$20 \mathrm{~cm}$ depth. To characterize soil nematode community, a further set of soil samples was collected close to previous ones. The sampling was carried out using a hand auger $(5 \mathrm{~cm}$ inside diameter) from the $20 \mathrm{~cm}$ deep top layer of bulk soil. For each soil sample, six cores were randomly sampled and then mixed to form one composite sample. Each sample was then placed in a plastic bag, labelled and stored in a cold chamber at $4^{\circ} \mathrm{C}$.

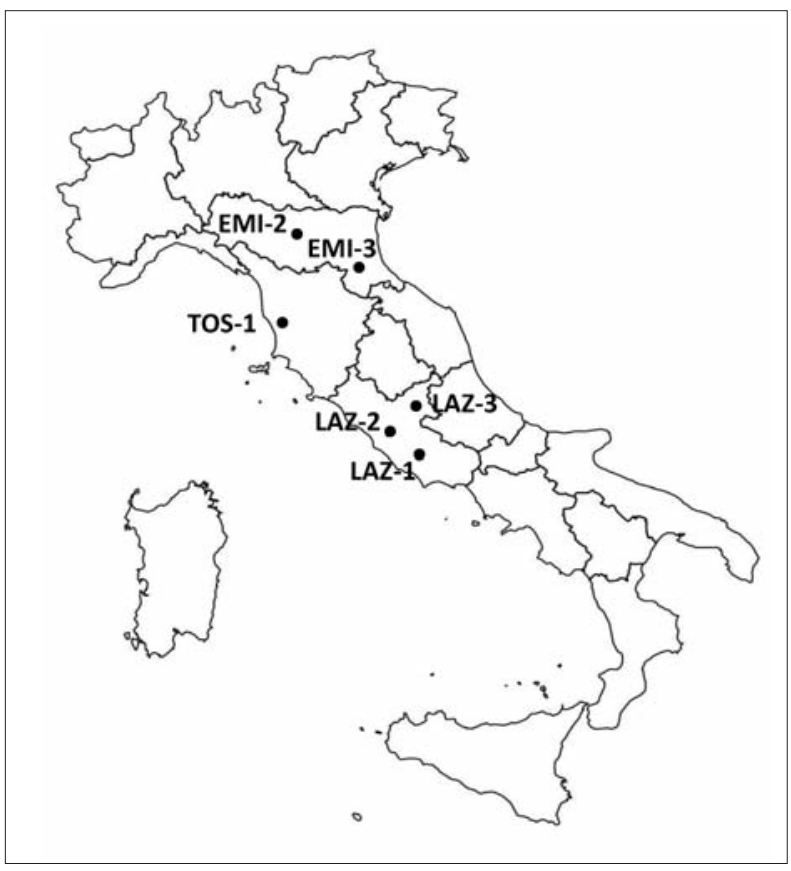

Fig. I - Monitored hop growing sites located in Northern and Central Italy.
SOIL PHYSICAL AND CHEMICAL ANALYSIS

The soil samples were air dried at room temperature $\left(\sim 20^{\circ} \mathrm{C}\right)$ and sieved through a $2 \mathrm{~mm}$ mesh for $\mathrm{pH}$ and texture, then through a $0.5 \mathrm{~mm}$ mesh for TOC. The texture was determined by modified pipette methods (INDORANTE et al., 1990). The soil $\mathrm{pH}$ was measured potentiometrically in a 1:2.5 soil-water suspension. TOC was determined by hot oxidation with potassium dichromate and sulphuric acid according to SPRINGER and KLEE (1954).

\section{SOIL NEMATODE COMMUNITY ANALYSIS}

Nematodes were isolated from $100 \mathrm{ml}$ of each soil sample using the cotton-wood filter extraction method. Nematodes were extracted for $48 \mathrm{~h}$ at room temperature, approximately $20^{\circ} \mathrm{C}$. Each nematode suspension was sieved through a 25 $\mu \mathrm{m}$ mesh and the nematodes were counted under a stereomicroscope (50x magnification). Nematodes were mounted on temporary slides and identified at higher magnification to species or genus level using keys from MAI et al. (1962), Bongers (1988), Cordero et al. (2012), MARINARIPalmisano and Vinciguerra (2014), Crozzoli, 2014. Taxonomic families were assigned to a trophic grouping based on YeATES et al. (1993) and OKADA et al. (2005). Nematode communities were characterised using: i) absolute abundance of individuals; ii) richness determined by counting the number of taxa; iii) the Maturity (MI) and Plant Parasitic (PPI) indices according to BoNGERs (1990); iv) diversity-weighted abundance $(\theta)$ calculated using biomass values (FERRIS, 2010) as reported by FERRIS and TUOMISTO (2015) in order to evaluate the ecosystem services efficiency. In addition, plant parasitic nematode communities were characterised using the relative abundance and the distribution frequency.

\section{STATISTICAL ANALYSIS}

One-way ANOVA was performed to assess the differences of sites on nematode taxa abundance, indicators of nematode community structure and $\theta$ index. When the $F$-test was significant at $P<0.05$, treatment means were compared using the Student-Newman-Keuls test using CoStat statistical software package (http://www.Cohort.com/costat.html). In addition, Canonical Correspondence Analysis (CCA) was carried out in order to link plant parasitic nematode communities (abundance of plant parasitic nematode taxa) and soil phys-

Table 1 - Characteristics of climate and management in the six selected sites.

\begin{tabular}{ccccccc}
\hline \hline Site & $\begin{array}{c}\text { Italian } \\
\text { Province }\end{array}$ & $\begin{array}{c}\text { Köppen } \\
\text { climate types }\end{array}$ & Previous crops & $\begin{array}{c}\text { Year of hops } \\
\text { implanting }\end{array}$ & Hops varieties & Agronomic management \\
\hline LAZ-1 & Latina & Csa $^{\text {b }}$ & Vineyard & 2014 & $\begin{array}{c}\text { Cascade, Chinook, Columbus, } \\
\text { Tettnanger }\end{array}$ & Conventional tillage \\
\hline LAZ-2 & Roma & Csa & Uncultivated & 2016 & Columbus, Yeoman, Cascade & Minimum tillage \\
\hline LAZ-3 & Rieti & Cfa $^{\text {c }}$ & $\begin{array}{c}\text { Crop rotation: } \\
\text { wheat/corn/ } \\
\text { vegetables }\end{array}$ & 2014 & $\begin{array}{c}\text { Hallertauer Magnum, Spalt } \\
\text { Spalter, Hallertau Mittelfrüh, } \\
\text { Northern Brewer, Perle, Saazer }\end{array}$ & Green cover \\
\hline TOS-1 & Pisa & Csa & $\begin{array}{c}\text { Mother plant for } \\
\text { vineyard }\end{array}$ & 2013 & $\begin{array}{c}\text { Northern Brewer, Fuggle, } \\
\text { Cascade, Perle, Centennial }\end{array}$ & Conventional tillage \\
\hline EMI-2 & $\begin{array}{c}\text { Reggio } \\
\text { Emilia }\end{array}$ & Cfa & Vineyard & 2016 & $\begin{array}{c}\text { Cascade } \\
\text { Conventional tillage }\end{array}$ \\
\hline Ravenna & Cfa & Nectarines & 2016 & $\begin{array}{c}\text { Cascade, Nugget, Centennial, } \\
\text { Sorachi Ace, Mounth Hood, } \\
\text { Crystal, Chinook, Fuggle }\end{array}$ & Conventional tillage \\
\hline
\end{tabular}

a The geographical coordinates are not available due to the lack of the farm owners' authorisation.

${ }^{\mathrm{b}}$ Hot-summer Mediterranean. 
ical and chemical variables (texture, soil $\mathrm{pH}$ and TOC) by the Past analysis package (HAMmer et al., 2001) (http://folk. uio.no/ohammer/past). Vectors represented the environmental axes; the length of vectors indicates the importance of the environmental variable with other variables; vectors in the same direction are positively correlated, while vectors pointing in opposite directions are negatively related. The statistical significance of the relationship between community and environmental variables was assessed by permutation test of both the first ordination axis and the combination of both the first and second axes.

\section{RESULTS}

SOIL PHYSICAL AND CHEMICAL PROPERTIES

Soil textures of sampled sites were classified according to the USDA Soil Taxonomy. EMI-2 and EMI-3, both in Emilia Romagna Region, were classified as clay loam and silty clay. The site located in Tuscany, TOS-1, was classified as sandy clay loam. Finally, in Latium Region, collected soils were classified as clay (LAZ-1 and LAZ-3) and clay loam (LAZ2). Soil $\mathrm{pH}$ values ranged from 6.7 to 8.2 in Emilia Romagna and Latium, respectively, while $\mathrm{pH}$ was 5.1 in Tuscany. The highest TOC value was found in LAZ-2, followed by LAZ3 and the lowest in TOS-1 (Table 2).

\section{SOIL NEMATODE COMMUNITY STRUCTURES}

Twenty-seven genera, belonging to twenty plant parasitic and free-living nematode families, were identified in soil samples collected in the six sites (Table 3). In general, the nematode population was low, only the Rhabditidae family was prominent among sites. Moreover, the abundance of Aphelenchidae and Dorilaymidae families were higher in LAZ-3 than in other sites. Conversely, the taxa richness was high in all sites except for TOS-1. Thirteen different genera of plant parasitic nematodes belonging to ten families were identified (Table 4). In general, the plant parasitic relative communities showed the absence of dominant species. Xiphinema pacthaicum was the most abundant species followed by Meloidogyne incognita, Mesocriconema xenoplax, and Helicotylenchus digonicus. Xiphinema pacthaicum was also the most widely distributed species among four sites, followed by M. xenoplax found in three sites. Finally, the species Pratylenchus penetrans, Ditylenchus sp., Rotylen chus robustus, $M$. incognita, and $X$. diversicaudatum were reported by less than $20 \%$ of sites. Other plant parasitic species occurred rarely.

\section{SOIL NEMATODE INDICATORS}

MI values ranged from 1.3 to 2 indicating the presence of generalist and opportunistic species (Table 3). Conversely, the PPI reached higher values (from 2.6 to 3.4 ) associated with the presence of families of persistent plant parasitic nematodes like Longidoridae. The MI and PPI were significantly higher in LAZ-3 than in other sites. Average values of diversity-weighted abundance $(\theta)$ are reported in Fig. II. The nematode assemblage was arranged in three functional classes: i) detritivores (bacterial and fungal feeders); ii) plant parasitic nematodes; iii) predators (including omnivores). The biomass of plant parasitic nematodes was significantly higher in EMI-2, LAZ-1, LAZ-2 and LAZ-3 than EMI-3 and TOS-1. By contrast, no significant differences were found in the other functional classes. In general, the detritivores channel was greater than other functional classes in all sites, while predator channel was low in all sites. Therefore, the regulation functions of opportunistic and plant parasitic nematodes by predation were insufficient: the predators/preys ratio ranged from 1:6.23 in LAZ-3 to 1:17.47 in EMI-3.

\section{RELATIONSHIP AMONG SOIL VARIABLES}

AND PLANT PARASITIC NEMATODE COMMUNITY STRUCTURE

In the CCA conducted between plant parasitic nematode taxa abundance (expressed as genus) and soil variables (texture, soil $\mathrm{pH}$ and TOC), the total variance explained by the first two axes was $56.7 \%$ (30.7\% axis 1 and $26 \%$ axis 2$)$. The ordination diagram in the plane defined by the first and second CCA axes were statistically significant for $P<0.04$ and $P<0.001$, respectively (Fig. III). Sand (0.72), TOC $(-0.68)$, soil $\mathrm{pH}(-0.67)$ clay $(-0.55)$ and silt $(-0.55)$ are the soil variables best correlated with axis 1 , whereas silt (0.52), soil $\mathrm{pH}(0.51)$ and sand $(-0.47)$ are best correlated with axis 2. CCA confirmed a clear separation of sites according to soil parameters; the main parameter was represented by the texture. The community variables were considered significant if their values exceed 1 . Thus, significant community variables were associated to genera: Tylenchorhynchus and Ditylenchus (dominated by sand content and inversely related to TOC), Heterodera (its dominant drivers were silt content and soil $\mathrm{pH}$ ), Paratylenchus genus (inversely related to soil pH). By contrast, Xiphinema and Mesocriconema genera were the least influenced by the environmental gradient established within the study areas.

\section{DISCUSSION}

The selected sites were representative of different climatic areas of Italy, soil types and agronomic practices allowing a broad evaluation of soil nematode communities associated to hop crops. In fact, the monitored area corresponded to $5 \%$ of the whole extent covered by hop crops in Italy and interested two climatic zones (Csa, Hot-summer Mediterranean; Cfa, Humid subtropical). The soil textures belonged to the main soil types (silty, sandy and clay soils) and a broad vari-

Table 2 - Soil physical and chemical properties of the topsoil $(0-20 \mathrm{~cm})$ in the six sites.

\begin{tabular}{ccccccc}
\hline \hline & Sand & Silt & Clay & Soil texture classification & Soil $\mathrm{pH}$ & TOC $\left(\mathrm{g} \mathrm{kg}^{-1}\right)$ \\
\hline LAZ-1 & $25.0 \pm 1.4$ & $24.6 \pm 0.4$ & $50.4 \pm 1.5$ & Clay & $6.7 \pm 0.2$ & $1.3 \pm 0.1$ \\
\hline LAZ-2 & $30.8 \pm 3.0$ & $36.7 \pm 4.4$ & $32.5 \pm 1.4$ & Clay loam & $7.3 \pm 0.1$ & $1.9 \pm 0.05$ \\
\hline LAZ-3 & $10.0 \pm 1.4$ & $30.0 \pm 3.8$ & $60.0 \pm 3.8$ & Clay & $7.8 \pm 0$. & $1.5 \pm 0.03$ \\
\hline TOS-1 & $73.3 \pm 1.7$ & $4.2 \pm 4.2$ & $22.5 \pm 2.5$ & Sandy clay loam & $5.1 \pm 0.1$ & $0.7 \pm 0.1$ \\
\hline EMI-2 & $15.0 \pm 1.4$ & $50.8 \pm 0.8$ & $34.2 \pm 2.2$ & Silty clay loam & $7.8 \pm 0.1$ & $1.3 \pm 0.04$ \\
\hline EMI-3 & $1.7 \pm 1.7$ & $42.5 \pm 1.4$ & $55.8 \pm 0.8$ & Silty clay & $8.2 \pm 0.02$ & $1.2 \pm 0.1$ \\
\hline
\end{tabular}


Table 3 - Abundance of nematode taxa (number of nematodes $100 \mathrm{ml}^{-1}$ soil). Samples were collected from the six sites during 2017 and 2018 $(\mathrm{n}=6)$. Standard errors are reported. Values in the row followed by different letters are significantly different at $P<0.05$. The significant $\mathrm{p}$ values are reported in bold.

\begin{tabular}{|c|c|c|c|c|c|c|c|}
\hline & LAZ-1 & LAZ-2 & LAZ-3 & TOS-1 & EMI-2 & EMI-3 & P-values \\
\hline Rhabditidae & $45.3 \pm 4.1$ & $49.0 \pm 7.9$ & $33.7 \pm 7.9$ & $36.3 \pm 12.8$ & $44.7 \pm 3.5$ & $48.7 \pm 6.6$ & 0.64 \\
\hline Monhysteridae & $0 \mathrm{~b}$ & $0 \mathrm{~b}$ & $0 \mathrm{~b}$ & $0 \mathrm{~b}$ & $0 \mathrm{~b}$ & $1.3 \pm 1.3 \mathrm{a}$ & 0.02 \\
\hline Cephalobidae & $4.0 \pm 1.5$ & $2.0 \pm 1.0$ & $7.0 \pm 2.3$ & $26.3 \pm 14.4$ & $7.0 \pm 0.6$ & $2.3 \pm 0.7$ & 0.11 \\
\hline Plectidae & $0 \mathrm{~b}$ & $1.3 \pm 0.7 \mathrm{a}$ & $0 \mathrm{~b}$ & $0 \mathrm{~b}$ & $0 \mathrm{~b}$ & $0 \mathrm{~b}$ & 0.02 \\
\hline Alaimidae & $4.7 \pm 1.2 \mathrm{a}$ & $0 \mathrm{~b}$ & $0 \mathrm{~b}$ & $0 \mathrm{~b}$ & $0 \mathrm{~b}$ & $0 \mathrm{~b}$ & 0.0001 \\
\hline Aphelenchidae & $0 \mathrm{~b}$ & $6.0 \pm 1.5$ & $8.3 \pm 1.9 \mathrm{a}$ & $4.3 \pm 0.7$ & $2.0 \pm 1.5$ & $3.0 \pm 1.0$ & 0.006 \\
\hline Discolaimidae & $0 \mathrm{~b}$ & $3.0 \pm 1.0 \mathrm{a}$ & $0 \mathrm{~b}$ & $0 \mathrm{~b}$ & $0 \mathrm{~b}$ & $1.0 \pm 1.0 \mathrm{~b}$ & 0.004 \\
\hline Dorylaimidae & $5.0 \pm 2.6 \mathrm{~b}$ & $6.0 \pm 1.5 \mathrm{~b}$ & $13.0 \pm 1.5 \mathrm{a}$ & $2.7 \pm 1.8 \mathrm{~b}$ & $10.0 \pm 1.0$ & $2.7 \pm 1.8 \mathrm{~b}$ & 0.004 \\
\hline Seinuridae & $1.0 \pm 0.6$ & $0.7 \pm 0.7$ & 0 & $0.7 \pm 0.74$ & $0.3 \pm 0.3$ & $1.0 \pm 1.0$ & 0.74 \\
\hline Mononchidae & $1.7 \pm 1.7$ & 0 & $1.7 \pm 0.9$ & $0 \mathrm{a}$ & $1.7 \pm 0.3$ & $0.3 \pm 0.3$ & 0.38 \\
\hline Tylenchidae & $0 \mathrm{~b}$ & $12.7 \pm 4.9 \mathrm{a}$ & $8.3 \pm 2.3$ & $7.0 \pm 1.2$ & $8.7 \pm 2.6$ & $2.0 \pm 0.6$ & 0.04 \\
\hline Paratylenchidae & $0.7 \pm 0.7$ & 0 & 0 & 0 & 0 & 0 & 0.46 \\
\hline Anguinidae & 0 & $0.7 \pm 0.7$ & $0.7 \pm 0.7$ & $2.0 \pm 1.0$ & $2.3 \pm 1.5$ & 0 & 0.26 \\
\hline Pratylenchidae & $2.7 \pm 1.3$ & 0 & $0.7 \pm 0.7$ & $5.3 \pm 2.7$ & $3.0 \pm 0$ & 0 & 0.07 \\
\hline Hoplolaimidae & $7.0 \pm 4.0$ & $1.3 \pm 1.3$ & $3.0 \pm 3.0$ & 0 & $7.7 \pm 2.9$ & $3.3 \pm 0.9$ & 0.25 \\
\hline Criconematidae & $2.7 \pm 1.8$ & 0 & $1.3 \pm 0.9$ & 0 & $4.0 \pm 2.1$ & $1.3 \pm 0.7$ & 0.21 \\
\hline Heteroderidae & $0 \mathrm{~b}$ & $1.7 \pm 0.9 \mathrm{~b}$ & $0 \mathrm{~b}$ & $0 \mathrm{~b}$ & $1.0 \pm 1.0 \mathrm{~b}$ & $6.0 \pm 3.2 \mathrm{a}$ & 0.05 \\
\hline Meloidogynidae & $6.3 \pm 6.3$ & $7.8 \pm 7.8$ & 0 & 0 & 0 & 0 & 0.20 \\
\hline Dolichodoridae & $2.3 \pm 0.3 \mathrm{a}$ & $0 \mathrm{~b}$ & $0 \mathrm{~b}$ & $0 \mathrm{~b}$ & $0 \mathrm{~b}$ & $0 \mathrm{~b}$ & 0.00001 \\
\hline Longidoridae & $6.0 \pm 1.2$ & $7.0 \pm 0.6 \mathrm{a}$ & $6.7 \pm 1.3 \mathrm{a}$ & $0 \mathrm{~b}$ & $6.3 \pm 1.8 \mathrm{a}$ & $0 \mathrm{~b}$ & 0.0005 \\
\hline Total abundance & $89.3 \pm 2.2$ & $99.0 \pm 10.7$ & $85.3 \pm 13.1$ & $84.7 \pm 9.5$ & $98.7 \pm 3.5$ & $73.0 \pm 6.4$ & 0.32 \\
\hline Taxa richness & $9.3 \pm 0.3 \mathrm{a}$ & $9.0 \pm 0.6 \mathrm{a}$ & $9.3 \pm 0.3 \mathrm{a}$ & $6.7 \pm 0.7 \mathrm{~b}$ & $11.0 \pm 0.6 \mathrm{a}$ & $9.0 \pm 0.6 \mathrm{a}$ & 0.003 \\
\hline$M I$ & $1.6 \pm 0.0$ & $1.6 \pm 0.1$ & $2.0 \pm 0.1 a$ & $1.6 \pm 0.2$ & $1.6 \pm 0.1$ & $1.3 \pm 0.1 b$ & 0.05 \\
\hline PPI & $3.2 \pm 0.2$ & $3.1 \pm 0.3$ & $3.4 \pm 0.2 a$ & $2.6 \pm 0.2 b$ & $3.2 \pm 0.2$ & $2.8 \pm 0.1$ & 0.05 \\
\hline
\end{tabular}

ability was also revealed in soil $\mathrm{pH}$ values, from acid to sub alkaline to alkaline. Being recent hop plants (established from 2013 to 2016 in all sites), soil organic carbon content was affected both by previous managements and current agronomic practices. LAZ-2 and LAZ-3 showed the highest organic matter content close to $2 \%$, which is considered as the critical threshold for soil quality in temperate region (LOVELAND and LEGENDRE, 1988). In these sites, conservative agronomic techniques have been applied both before and after hop planting. LAZ-2 was uncultivated since 2016 and then the hop cultivation was managed by minimum tillage, LAZ-3 was managed by crop rotation since 2014 and then by green cover. By contrast, the traditional tillage has caused low content of organic matter. In particular, the sandy soil with acid $\mathrm{pH}$ showed the lowest values.

\section{SOIL NEMATODE STRUCTURE}

A great variability in soil nematode community was found among different climatic areas, soil types and agronomic managements, according to NEHER et al. (1995).

Many plant parasitic nematodes widely distributed in Italy were also found associated with hop plants such as the ring nematode M. xenoplax common on fruit trees in Europe and reported associated with hop only in South Africa (NYCZEPIR and Halbrendt, 1993; Crozzoli, 2014; Gargani et al., 2017). This species is known to occur, also, in grape-growing areas in Italy (MALOSSINI et al., 2008; MALOSSINI et al., 2011) and it often causes significant economic losses in the grape wine areas of the world (TÉLIZ et al., 2007). The ring nematode is often occurring in association with Xiphinema spp. (AMBRoGIONI and D'ERRICO, 1980). H. humuli, the most common species infesting hop in Europe, was not found during this survey, but other species belonging to Heterodera genera were found: $H$. carotae, $H$. schachtii and $H$. cruciferae were detected in LAZ-2, EMI-2 and EMI-3, respectively. No dominant plant parasitic nematode species have been found in any site, however the species belonging to Xiphinema genus were widely distributed in the study areas and some of them could transmit plant virus. The most frequent species were $X$. pacthaicum followed by $X$. diversicaudatum. The Arabis mosaic virus (ArMV), the most common nepovirus identified in hop and transmitted by $X$. diversicaudatum has not been found yet in Italy (GARGANI et al., 2017), but the presence of this virus-vector nematodes $X$. diversicaudatum is of particular concern. Multiple plant parasitic nematode association and/or their interaction with virus or fungi may also constitute a problem because this can cause synergistic damages to plants (RAGOZZINO and D'ERRICO, 2011; ANWAR and MCKenRY, 2012).

Several genera of plant parasitic nematodes were affected by soil parameters. CCA suggested that edaphic variables soil texture, $\mathrm{pH}$ and organic carbon, are the primary determinants that influence the structure and diversity of plant parasitic nematode community. The texture influenced three genera: Heterodera was favoured by silt content, while genera Ditylenchus and Tylenchorhynchus increased with high sand content. As reported by PEDERSEN et al. (2010), Heterodera genus was also influenced by soil $\mathrm{pH}$. In fact, the population density was associated with high soil $\mathrm{pH}$. In accordance with BARKER and KOENING (1998), BIRD (2000) and LANDI et al. (2016), the increase of organic matter content was negatively correlated with plant parasitic nematodes 
Table 4-Specific structure of plant parasitic nematode communities in hop sites.

\begin{tabular}{|c|c|c|c|}
\hline Nematode species & $\begin{array}{c}\text { Mean value } \\
\quad \mathrm{X} \pm \mathrm{SE}\end{array}$ & $\begin{array}{c}\text { Relative } \\
\text { abundance \% }\end{array}$ & $\begin{array}{l}\text { Distribution } \\
\text { frequency \% }\end{array}$ \\
\hline \multicolumn{4}{|l|}{ Tylenchidae } \\
\hline Tylenchorhynchus sp. & $0.4 \pm 0.4$ & 2.3 & 5.6 \\
\hline \multicolumn{4}{|l|}{ Paratylenchidae } \\
\hline \multicolumn{4}{|l|}{ Anguinidae } \\
\hline Ditylenchus dipsaci (Kühn) Filipjev & $0.4 \pm 0.3$ & 2.3 & 11.1 \\
\hline Ditylenchus sp. & $0.6 \pm 0.3$ & 3.2 & 22.2 \\
\hline \multicolumn{4}{|l|}{ Pratylenchidae } \\
\hline Pratylenchus penetrans (Cobb) Filipjev and Schuurmans Stekhoven & $0.8 \pm 0.3$ & 4.5 & 27.8 \\
\hline Pratylenchus vulnus Allen and Jensen & $0.2 \pm 0.2$ & 1.3 & 5.6 \\
\hline Pratylenchus sp. & $1.0 \pm 0.6$ & 5.8 & 16.7 \\
\hline \multicolumn{4}{|l|}{ Hoplolaimidae } \\
\hline Helicotylenchus digonicus Perry in Perry, Darling and Thorne & $1.4 \pm 0.6$ & 8.4 & 27.8 \\
\hline Helicotylenchus sp. & $0.3 \pm 0.2$ & 1.9 & 11.1 \\
\hline Rotylenchus robustus (de Man) Filipjev & $0.7 \pm 0.3$ & 3.9 & 22.2 \\
\hline Rotylenchus sp. & $1.3 \pm 0.8$ & 7.4 & 16.7 \\
\hline \multicolumn{4}{|l|}{ Criconematidae } \\
\hline Mesocriconema xenoplax (Raski) Loof and De Grisse & $1.4 \pm 0.5$ & 8.4 & 44.4 \\
\hline Criconema sp. & $0.1 \pm 0.1$ & 0.6 & 5.6 \\
\hline \multicolumn{4}{|l|}{ Meloidogynae } \\
\hline Meloidogyne incognita (Kofoid and White) Chitwood & $2.3 \pm 1.2$ & 13.5 & 22.2 \\
\hline \multicolumn{4}{|l|}{ Heteroderidae } \\
\hline Heterodera carotae Jones & $0.3 \pm 0.2$ & 1.6 & 11.1 \\
\hline Heterodera cruciferae Jones & $1.0 \pm 0.7$ & 5.8 & 11.1 \\
\hline Heterodera schachtii Schmidt & $0.2 \pm 0.2$ & 1 & 5.6 \\
\hline \multicolumn{4}{|l|}{ Dolichodoridae } \\
\hline Merlinius brevidens (Allen) Siddiqi & $0.4 \pm 0.2$ & 2.3 & 16.7 \\
\hline \multicolumn{4}{|l|}{ Longidoridae } \\
\hline Longidorus macrosoma Hooper & $0.2 \pm 0.1$ & 1.3 & 16.7 \\
\hline Xiphinema diversicaudatum (Micoletzky) Thorne & $0.9 \pm 0.4$ & 5.2 & 22.2 \\
\hline Xiphinema italiae Meyl & $0.4 \pm 0.2$ & 2.3 & 16.7 \\
\hline Xiphinema pacthaicum (Tulaganov) Kirjanova & $2.8 \pm 0.6$ & 16.4 & 66.7 \\
\hline
\end{tabular}

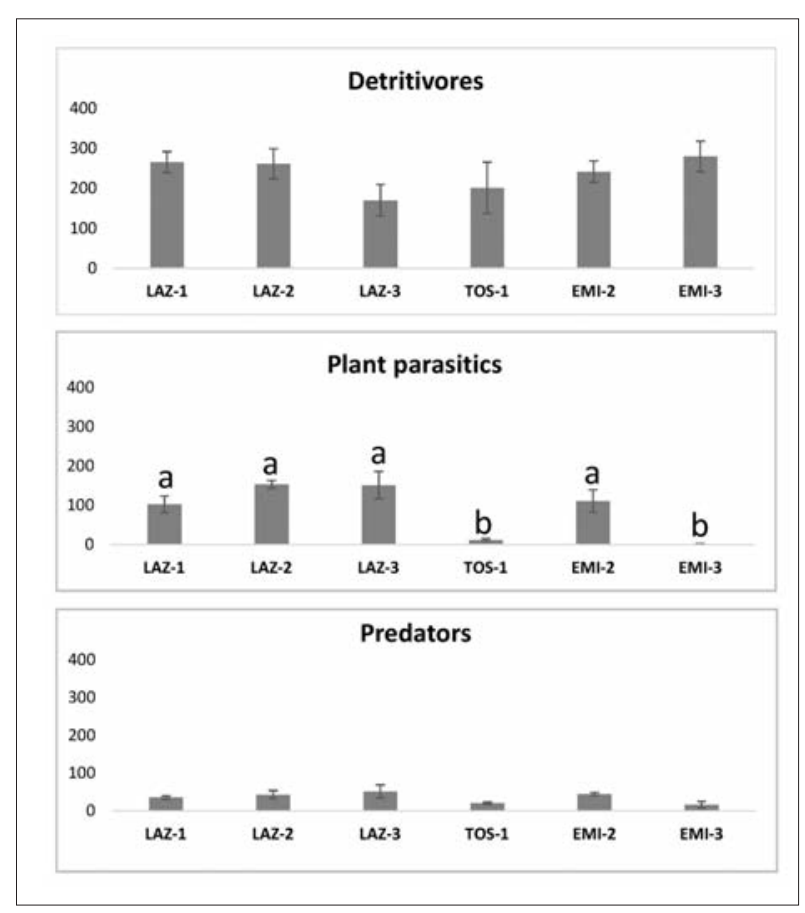

Fig. II - Diversity-weighted abundance $(\theta)$ expressed as biomass for functional classes of soil nematode assemblages in six sites located in three Italian regions: Lazio (LAZ-1, LAZ-2 and LAZ-3), Tuscany (TOS-1) and Emilia Romagna (EMI-1 and EMI-2). belonging to the genera Ditylenchus and Tylenchorhynchus. By contrast, in these study areas the genera Mesocriconema (harmful for vineyards) and Xiphinema (vector of plant virus) resulted ubiquitous. As reported by HARRISON and WinsLOW (1961) and BoAG et al. (1991) Xiphinema genus could be expected to require well-aerated soils, whereas they are also found in soil with medium or heavy texture. Moreover, the increment of native soil organic matter did not suppress larger nematodes. At this regard, PONCHILlia (1972) found that only large additions of organic matter as muck have a deleterious effect on Xiphinema species.

The nematode indicators showed that the nematode community composition varied as a result of the previous and current agricultural practices. In fact, the LAZ-3 site, characterized by previous crop rotation and the current cover grass management, showed the highest values in MI and PPI indices. The lack of soil tillage may have reduced the negative impact on the nematode populations, as previously reported (THOMAS, 1978; WARDE, 1995; LANDI et al., 2018a; 2018b). In contrast, the lowest MI value was found where the agronomic technique included annual deep ploughing. In the context of ecosystem services, nematode community plays an important role in pest control (regulating services) and in nutrient recycling (supporting service). Nematode predators provide to regulate plant parasitic nematodes, while detritivores and predators provide nutrient recycling service. The use of diversity-weighted abundance expressed as biomass showed that the predators are unable to regulate 


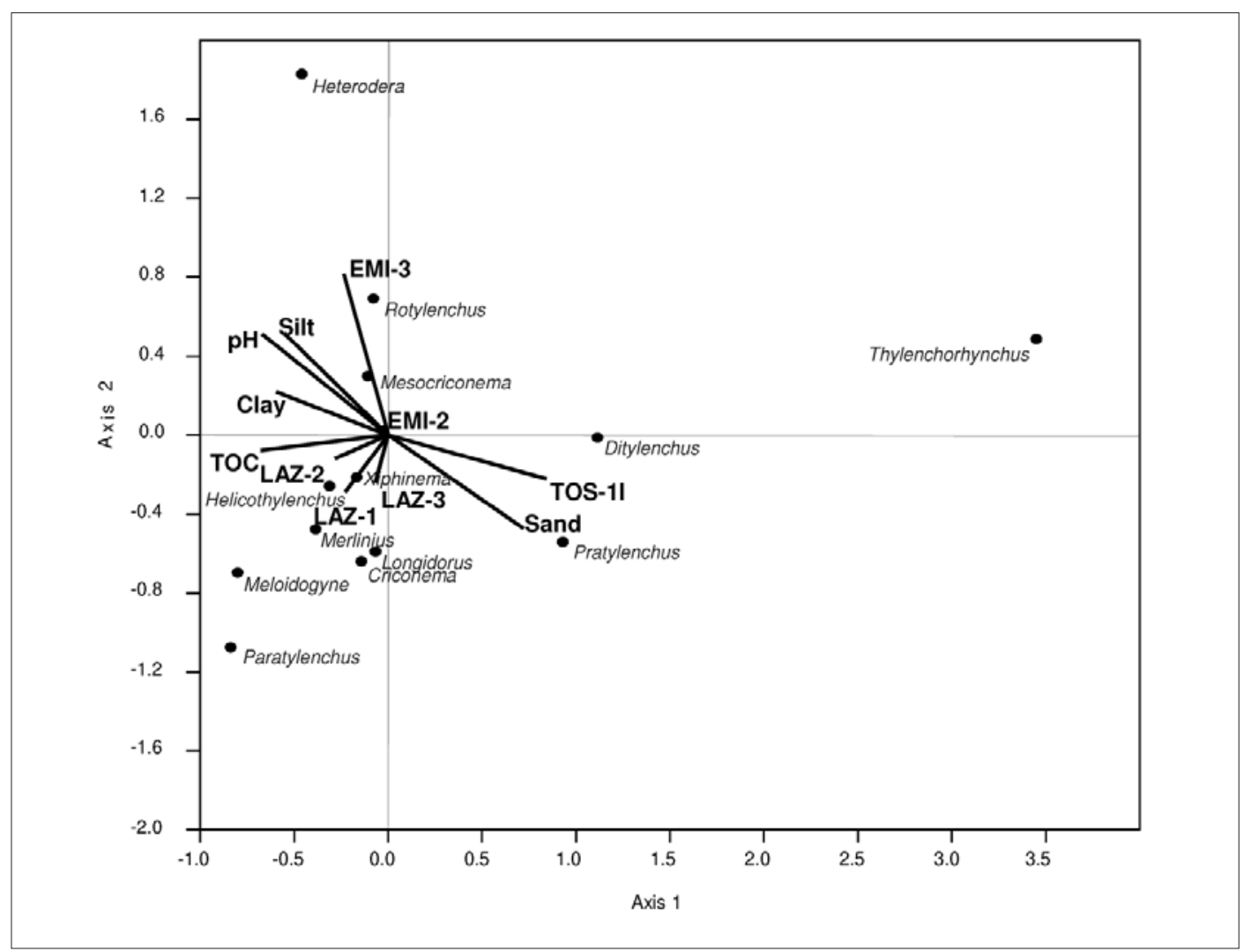

Fig. III - Scatter plot of CCA ordination showing relationships between soil properties and plant parasite nematode taxa abundance. Percentage of variance explained was $30.7 \%$ for axis $1(P<0.04)$ and $26 \%$ for axis $2(P<0.001)$.

the ecosystem services of plant parasitic nematodes and carbon mineralization. However, the differences among sites were relevant: the site previously managed using crop rotation and then by grass cover showed the best regulation.

\section{CONCLUSION}

By evaluating six different sites located in Northern and Central Italy, we are able to assess the structure of nematode communities. Overall, with regard to plant parasitic nematodes, the virus-vector Xiphinema genus is the most abundant and widely distributed and for this reason periodic soil monitoring is necessary to evaluate the phytosanitary status. Moreover, the predators were not able to regulate the ecosystem services and in particular the pest control service. At this purpose, agronomic practices that reduce tillage such as minimum tillage or, better, cover grass are recommended.

\section{ACKNOWLEDGMENTS}

Financial support for this work was provided by the Ministero delle Politiche Agricole Alimentari e Forestali (MiPAAF) under the Project LUPPOLO.IT "Miglioramento competitivo e qualitativo del luppolo da birra".

\section{REFERENCES}

Ambrogioni L., D’ERrico F.P., 1980 - Macroposthonia xenoplax (Raski, 1952) De Grisse et Loof, 1965 su viti in deperimento in Campania. - Atti Giornate Fitopatologiche, pp. 523-530.
ANWAR S.A., McKenRY M.V., 2012 - Incidence and population density of plant-parasitic nematodes infecting vegetable crops and associated yield losses in Punjab, Pakistan. - Pakistan Journal of Zoology, 44(2): 327-333.

BARKER K.R., KoENNING S.R., 1998 - Developing sustainable systems for nematode management. - Annual Review of Phytopathology, 36: 165-205.

BIRD G., 2000 - Nematodes and soil ecology. - Michigan Field Crop Ecology, E-2704.

Boag B., Crawford J.W., Neilson R., 1991- The effect of potential climatic changes on the geographical distribution of the plant-parasitic nematodes Xiphinema and Longidorus Us in Europe. - Nematologica, 37: 312-323.

Bongers T., 1988 - De Nematoden van Nederland. K. N. N. $V$. - Utrecht, The Nederlands.

BONGERS T., 1990 - The maturity index: an ecological measure of environmental disturbance based on nematode species composition. - Oecologia, 83: 14-19.

Carbone K., Amoriello T., Pagano M., Sperandio G., Assirelli A., Tarangioli S., Monteleone A., 2017 Prospettive interessanti per il luppolo italiano. L'informatore Agrario, 20: 49-51.

Cordero M.A., Robbins R.T., Szalanski A.L., 2012 Taxonomic and molecular identification of Mesocriconema and Criconemoides species (Nematoda: Criconematidae). - Journal of Nematology, 44 (4): 399426.

Crozzoli R., 2014 - Nematodi ectoparassiti. - In: Ambrogioni L., d'Errico F.P., Greco N.A., MarinariPalmisano A., Roversi P.F. (Eds.), Nematologia Agraria generale e applicata. Società Italiana di Nematologia, Bari, pp. 279-301. 
DANILOVA YU S., 1996 - Bio-ecological justification of control measures of hop against hop cyst nematode Heterodera humuli Filipjev, 1934. - PhD Thesis. Moscow: TSKhA: 22.

D’ERRICO G., CRESCENZI A., LANDI S., 2014 - First report of the southern root-knot nematode Meloidogyne incognita on the invasive weed Araujia sericifera in Italy. - Plant Disease, 98 (11): 1593-1593.

FERRIS H., 2010 - Form and function: metabolic footprints of nematodes in the soil food web. - European Journal of Soil Biology, 46: 97-104.

FERRIS H., TUOMISTO H., 2015 - Unearthing the role of biological diversity in soil health. - Soil Biology and Biochemistry, 85: 101-109.

Gargani E., Ferretti L., Faggioli F., Haegi A., Luigi M., Landi S., Simoni S., Benvenuti C., Guidi S., Simoncini S., D'Errico G., Amoriello T., Ciccoritti R., Roversi P. F., CARBONE K., 2017 - A survey on pests and diseases of Italian Hop crops. - Italus Hortus, 24 (2): 1-17.

HAMMER Ø., HARPER D., RYAN P., 2001 - PAST - palaeontological statistics, ver. 1.89. - Palaeontologia Electronica, 4: 1-9.

HARRISON B.D., WINSLOW R.D., 1961 - Laboratory and fields studies on the relation of arabis mosaic virus to its nematode vector Xiphinema diversicaudatum (Micoletzky). - Annals of Applied Biology, 49: 612-633.

HAY F.S., 2010 - Hot Cyst Nematode. In Field guide for integrated pest management in hops. - Technica Editors Gent D.H., Barbour J.D. Drevers A.J., James D.G., Parker R., Walsh D. B. A Cooperative publication produced by Oregon State University, University of Idaho, and Washington State University, pp. 85.

Indorante S.J., Hammer R.D., Koening P.G., Follmer L.R., 1990 - Particle-size analysis by modified pipette procedure. - Soil Science Society of America Journal, 54 (2): 560-563.

Landi S., Pennacchio F., Papini R., D’Errico G., Torrini G., Strangi A., Barabaschi D., Roversi P.F., 2016 Evaluation of sheep grazing effects on nematode community, insect infestation and soil fertility in sweet chestnut orchards: a case of study. - Redia, 99: 117-126.

Landi S., Papini R., D’ERrico G., Brandi G., Rocchini A., Roversi P.F., Bazzoffi P., Mocali S., 2018a - Effect of different set-aside management systems on soil nematode community and soil fertility in North, Central and South Italy. - Agriculture, Ecosystems and Environment, 261: 251-260.

Landi S., Papini R., D'ERrico G., Barzanti G.P., Roversi P.F., 2018b - Nematode indicators as integrative measures of soil condition during conversion from conventional to organic rice production in Italy: a case study. -Biological agriculture \& horticulture, 34 (3): 141-153.

Lazzaro L., Mazza G., D’Errico G., Fabiani A., Giuliani C., Inghilesi A.F., LAGOMARSINO A., LANDI S., LASTRUCCI L., Pastorelli R., Roversi P.F., Torrini G., Tricarico E., FOGGI B., 2018 - How ecosystems change following invasion by Robinia pseudoacacia: Insights from soil chemical properties and soil microbial, nematode, microarthropod and plant communities. - Science of the Total Environment, 622: 1509-1518.

LIŠKOVÁ M., RENČO M., 2007 - Communities of free living and plant parasitic nematodes in hop gardens in Slovakia. - Helminthologia, 44 (2): 80-86.

LOVELAND P., LEGENDRE L., 1998 - Is there a critical level of organic production practices on soil quality indicators? Journal of Environmental Quality, 28: 1601-1609.

MAI W.F., LyON H.H., KRUK T.H., 1964. - Pictorial key to genera of plant parasitic nematodes. - Ithaca (NY): Plates Reproduced by Art Craft of Ithaca Inc.

Malossini U., Ioriatti C., Mescalchin E., Varner M., GiacometTi R., D'ERRICO F.P., 2008 - Nematofauna associated to grapevine in Trentino (Northern Italy). - Redia, 91: 147-150.

Malossini U., D’ERrico G., VARner M., D’ERrico F.P., SOPPELSA O., 2011 - The vertical and horizontal distribution of Mesocriconema xenoplax (Raski, 1952) in Trentino vineyards (Northern Italy). - Redia, 94: 153-157.

MARINARI-PALMISANO A., VINCIGUERRA M., 2014 Classificazione dei nematodi. - In: Ambrogioni L., d'Errico F.P., Greco N.A., Marinari-Palmisano A., Roversi P.F. (Eds.), Nematologia Agraria generale e applicata. Società Italiana di Nematologia, Bari, pp. 23-42.

Mocali S., Landi S., Curto G., Dallavalle E., Infantino A., Colzi C., D'Errico G., Roversi P.F., D'Avino L., LAZZERI, L., 2015a - Resilience of soil microbial and nematode communities after biofumigant treatment with defatted seed meals. - Industrial Crops and Products, 75: 79-90.

Mocali S., Landi S., Fabiani A., Piccolo R., Agnelli A., D’Errico G., Mazza G., Fedrizzi M., Sperandio G., Guerrieri M., Pagano M., Puri D., Bazzoffi P., Biagini M., Lo CASCIO P., CoRTI C., 2015b - Environmental effectiveness of GAEC cross-compliance Standard 4.2 on biodiversity in set-aside management and economic evaluation of the competitiveness gap for farmers, part I. - Italian Journal of Agronomy, 10 (s1):711.

Neher D.A., Peck S.L., Rawlings J.O., CAmpbell C.I., 1995 - Measures of nematode community structure and sources of variability among and within agricultural fields. - Plant Soil, 170: 167-181.

NyCZEPIR A.P., HALBRENDT J.M., 1993 - Nematode pests of deciduous fruit and nut trees. - In: Evans K., Trudgill D.L., Webster J.M., Plant Parasitic Nematodes in Temperate Agriculture. CAB International (Wallingform, U.K.): 381425.

OKada H., Harada H., Kadora I., 2005 - Fungal-feeding habits of six nematode isolates in the genus Filenchus. Soil Biology and Biochemistry, 37: 1113-1120.

Pedersen P., Tylka G.L., Mallarino A., Macguidwin A.E., Koval N.C., Grau C.R., 2010 - Correlation between soil $\mathrm{pH}$, Heterodera glycines population densities, and soybean yield. - Crop Science, 50: 1458-1464.

Percival J., 1895 - An eelworm disease of hops. - Natural Science, 5: 187-197.

PONCHILLIA P.E., 1972 - Xiphinema americanum as affected by soil organic matter and porosity. - Journal of Nematology, 4 (3): 189-193.

RAGOZZINO A., D'ERRICO G., 2011 - Interactions between nematodes and fungi: a concise review. - Redia, 44: 123125.

SPRINGER U., KLEE J., 1954 - Prufung der Leistungsfa higkeit von einigen wichtigen Verfahren zur Bestimmung des Kohlenstoffs mittels Chromschwefelsaure sowie Vorschlag einer neuen Schnellmethode [Testing the performance of some important methods for the determination of carbon by means of chromosulfuric acid and proposing a new rapid method]. - Journal of Plant Nutrition and Soil Science, 64: 1-26.

Téliz D., Landa B.B., Rapoport H.F., Camacho F.P., JimÉnEZ-DíAz R.M., CASTILlo P., 2007 - Plant-parasitic nematodes infecting grapevine in southern Spain and susceptible reaction to root-knot nematodes of rootstocks reported as moderately resistant. - Plant Disease, 91 (9): 1147-1154

Thomas S.H., 1978 - Populations densities of nematodes 
under seven tillage regimes. - Journal of Nematology, 10: 24-27.

Valdez R.B., McNamara D.G., Ormerod P.J., Pitcher R.S., Thresh J.M., 1974 - Transmission of the hop strain of Arabis mosaic virus by Xiphinema diversicaudatum. Annals of Applied Biology, 76: 113-122.

Voigt W., 1894 - Neue Varietät des Rübennematoden (Heterodera schacthii) S. B. niederrhein. - Ges. Nat. Heilk., 51: 94-97.
WARDE D.A., 1995 - Impacts of disturbance on detritus food webs in agro-ecosystems of contrasting tillage and weed management practices. - Advances in Ecological Research, 26: 105-185.

Yeates G.W., Bongers T., De Goede R., Freckman D., GEORGIEVA S., 1993 - Feeding habits in soil nematode families and genera in outline for soil ecologists. - Journal of Nematology, 25: 315-331. 